\title{
PEMANFAATAN ALAT PENJERNIH AIR BERBASIS KAYU BAKAU DAN BATU APUNG
}

\section{The Utilization of Water Cleaning Devices Based on Magrove Wood And Floating Stone}

\author{
Alfina T Alaydrus, Kasnawi Al Hadi, Laili Mardiana, Teguh Ardianto, Susi Rahayu* \\ ${ }^{1}$ Program Studi Fisika Universitas Mataram \\ Jalan Majapahit Nomor 62 Kota Mataram Provinsi NTB \\ *Alamat korespondensi : susirahayu@unram.ac.id \\ (Tanggal Submission: 7 Oktober 2020, Tanggal Accepted: 28 Desember 2020)
}

\begin{abstract}
ABSTRAK
Desa Pelangan merupakan salah satu daerah penambangan emas di Sekotong Barat. Aktivitas penambangan dilakukan secara legal maupun ilegal. Aktivitas penambangan secara illegal dilakukan menggunakan peralatan sederhana tanpa memperhatikan keselamatan kerja dan keselamatan lingkungan akibat pengolahan emas. Lingkungan yang tercemar mulai dirasakan warga dengan tercemarnya air di desa ini. Pencemaran yang terjadi diantaranya air yang berbau dan warna air yang keruh. Sehingga, perlu dilakukan pengabdian untuk memberikan pengetahuan cara membuat alat filtrasi dan cara menjernihkan air berbasis kayu bakau dan batu apung. Kayu bakau dipotong secara homogen dan dilakukan pembakaran hingga hitam sempurna, sedangkan batu apung ditreatment dengan dibuat dalam bentuk partikel dan utuh. Kemampuan dari kedua bahan utma ini sebagai absorben akan sangat membantu proses filtrasi. Dari hasil pengabdian ini, masyarakat sangat antusias karna memperoleh air yang layak untuk dipakai. Hasil yang diperoleh dari alat penjernih ini yaitu air menjadi lebih jernih, tidak berbau, dan layak untuk dipakai. Pembuatan alat ini menjadi salah satu solusi yang dapat diterapkan masyarakat desa Pelangan untuk memperoleh air bersih.
\end{abstract}

Kata kunci: Arang Karbon, batu apung, penjernih air

\section{PENDAHULUAN}

Desa Pelangan merupakan salah satu dari dari tiga desa yang merupakan lokasi utama penambangan emas baik secara legal maupun illegal. Namun, sebagain besar aktivitas penambangan dilakukan secara illegal dan tradiosional. Kegiatan tersebut dilakukan karena mudah dan murah. Aktivitas tersebut memiliki banyak dampak negative diantaranya pencemaran air, gangguan kesehatan, pencemaran udara, dan lain-lain. Proses pengolahan emas menghasilkan beberapa limbah cair seperti logam-logam berat yang memberi efek berbahaya bagi tubuh dan lingkungan (Sancayaningsih, 2010).

Pencemaran lingkungan yang sering terjadi yaitu pencemaran air. Pencemaran air 
merupakan salah satu masalah yang sangat penting untuk diperhatikan, karena air sangat dibutuhkan dalam kehidupan. Keberadaan air yang tercemar akan sangat mengganggu sistem kehidupan, karena makhluk hidup membutuhkan air dengan kualitas yang baik dan kuantitas yang cukup serta ketersediaannya harus cukup kontinu (Sariwati 2010). Salah satu sumber air yang biasa digunakan oleh warga desa Pelangan yaitu air sumur. Air sumur di sebagian besar rumah warga sudah tercemar akibat aktivitas penambangan yang dilakukan.

Untuk mengurangi efek dari pencemaran lingkungan yang berdampak terhadap kualitas air, diperlukan suatu teknologi penjernih air yang efektif dan efisien. Sejak puluhan tahun, teknologi penjernih air telah berkembang dengan pesat. Metode penjernih air dapat dilakukan dengan teknologi membrane, koagolasi, filtrasi dan lain-lain. Adapun jenis filtrasi dengan teknologi membran membran menurut tingkat filtrasinya dibedakan menjadi membran microfiltration (MF), ultrafiltration (UF), nanofiltration (NF) dan reversible osmosis (RO) (Bahareh dkk, 2014). Salah satu teknologi yang biasa digunakan yaitu teknologi filtrasi. Teknologi filtrasi yang aman dan mudah biasanya memanfaatkan bahan alam sebagai bahan bakunya.

Pada kegiatan pengabdian ini, digunakan kayu bakau dan batu apung sebagai sumber adsorbennya. Karakteristik utama dari adsorben yaitu bahan berpori. Bahan alam berpori diantaranya karbon dari kayu bakau dan batu apung. Karbon dari kayu bakau dapat dimanfaatkan sebagai adsorben. Karbon aktif mampu meyerap zat berbahaya seperti logam (Caroline dkk, 2017). Selain itu, karbon aktif juga mampu menyerap mampu menyerap warna dan bau dalam air (Fuadi dkk, 2008). Karbon aktif dapat dibuat dari limbah terbuang seperti kayu bakau yang banyak ditemukan di daerah pesisir.

Selain kayu bakau, batu apung merupakan salah satu bahan alam yang melimpah di Lombok dan dapat dimanfaatkan sebagai adsorben juga. Batu apung merupakan batuan vulkanik berpori yang mengandung silika ( $\mathrm{SiO2}$ ) dan alumina (Al2O3), dan zat besi yang rendah (Trianasari, 2017). Kadar silica dalam batu apung sekitar $48 \%$ dan komponen Al2O3 sebanyak 14,9\% (Mourhly dkk, 2015). Sedangkan dari hasil penelitian Ersoy (2010), terdapat kandungan lain dalam batu apung yaitu $\mathrm{MgO}, \mathrm{Na2O}, \mathrm{CaO}, \mathrm{Fe} 2 \mathrm{O} 3, \mathrm{~K} 2 \mathrm{O}$, dan lainlainnya.

Batu apung dan kayu bakau adalah bahan alam yang mudah diperoleh di lokasi pengabdian. Beberapa kondisi yang disebutkan diatas menjadi alasan pentingnya dilakukan pengabdian untuk memberikan pengetahuan cara membuat alat filtrasi dan cara menjernihkan air berbasis kayu bakau dan batu apung. Kegiatan pengabdian ini meliputi tiga kegiatan utama yaitu sosialisai pentingnya menjaga kesehatan lingkungan, workshop pembuatan alat filtrasi berbasis kayu bakau dan batu apung, serta evaluasi kegiatan. Sehingga melalui serentetan kegiatan ini, warga setempat mampu secara mandiri membuat alat penjernih air untuk memenuhi kebutuhan air rumah tangga.

\section{METODE KEGIATAN}

Kegiatan pengabdian masyarakat di desa Pelangan Kabupaten Sekotong Barat dilakukan untuk memberikan pengetahuan cara membuat alat filtrasi dan cara menjernihkan air 
berbasis kayu bakau dan batu apung dilakukan dengan tiga tahapan utama yaitu sosialisai pentingnya menjaga kesehatan lingkungan, workshop pembuatan alat filtrasi berbasis kayu bakau dan batu apung, serta evaluasi kegiatan. Adapun alat dan bahan yang digunakan yaitu pipa air, tutup pipa, keran air, batu kerikil besar dan kecil, spon, pasir, karbon aktif dari kayu bakau, batu apung, dan ijuk. Secara terperinci metode pelaksanaannya dilakukan sebagai berikut :

\section{Sosialisasi}

Sosialisasi mengenai pentingnya menjaga kesehatan lingkungan dilakukan oleh tim pengabdian dengan dua metode yaitu presentasi dan diskusi. Presentasi dilakukan oleh dua orang dari tim dengan tema pencemaran lingkungan dan efek air tercemar bagi kesehatan. Presentasi dilakukan selama dua kali sepuluh menit yang diikuti dengan diskusi terbuka selama 30 menit. Tahapan ini diharapkan mampu memberikan pengetahuan pentingnya kesehatan lingkungan bagi kehidupan.

\section{Workshop}

Workshop pembuatan alat filtrasi berbasis kayu bakau dan batu apung dilakukan melalui tiga proses yaitu pembuatan desain alat, persiapan alat dan bahan, membuat alat filtrasi, dan mengaplikasikan alat filtasi air. Workshop dilakukan dengan membagi menjadi 5 kelompok dengan masing-masing kelompok terdiri dari 6 orang warga. Setiap kelompok akan diarahkan oleh 1-2 orang tim pengabdian. Desain alat dibuat secara bersama-sama dengan arahan dari tim pengabdian. Adapun proses preparasi bahan kayu bakau dan batu apung dilakukan dengan seksama. Kayu bakau dipotong-potong kemudian dibakar menggunakan api hingga menghasilkan warna hitam merata. Kemudian batu apung juga perlu dipreparasi dengan cara dicuci bersih menggunakan air dan dihaluskan hingga siap untuk diaplikasikan. Setelah preparasi bahan utama selesai, dilakukan pemotongan pipa sesuai kebutuhan. Selanjutnya seluruh bahan diletakkan sesuai desain yang telah dibuat dan diaplikasikan untuk menjernihkan air sumur.

\section{Evaluasi}

Tahapan evaluasi dilakukan untuk mengetahui keefektifan kegiatan pengabdian dilakukan. Metode yang digunakan pada tahapan ini yaitu metode tanya jawab dengan standart pertanyaan yang telah disiapkan oleh tim pengabdian. Melalui tahapan tersebut harapannya tim dapat mencatat kekurangan, kelebihan, dan respon dari peserta.

\section{HASIL DAN PEMBAHASAN}

Kegiatan pengabdian kepada masyarakat dengan judul pemanfaatan alat penjernih air berbasis kayu bakau dan batu apung di desa Pelangan, Sekotong Barat telah dilaksanakan pada bulan September 2019. Ketiga komponen pelaksanaan yang terdiri dari sosialisai pentingnya menjaga kesehatan lingkungan, workshop pembuatan alat filtrasi berbasis kayu bakau dan batu apung, serta evaluasi kegiatan berhasil dilaksanakan dengan jumlah peserta 30 orang. Keberhasilan ditolak ukur melalui proses evaluasi kegiatan.

Kegiatan sosialisasi pentingnya menjaga kesehatan lingkungan telah disampaikan dengan metode presentasi dan diskusi. Beberapa materi yang disampaikan meliputi jenis pencemaran lingkungan akibat 
aktivitas tambang dan berbagai efek kesehatan bagi tubuh akibat mengkonsumsi air yang tercemar. Pencemaran lingkungan yang terjadi dapat berupa pencemaran air, tanah dan udara. Adapun dampak yang diberikan akibat air sumur yang tercemar antara lain gangguan otak, saraf, kulit, dan lain-lain. Melalui kegiatan sosialisasi tersebut, mampu memberikan pemahaman kepada warga sekitar mengenai dampak aktivitas tambang dan pencemaran air yang berbahaya bagi manusia.

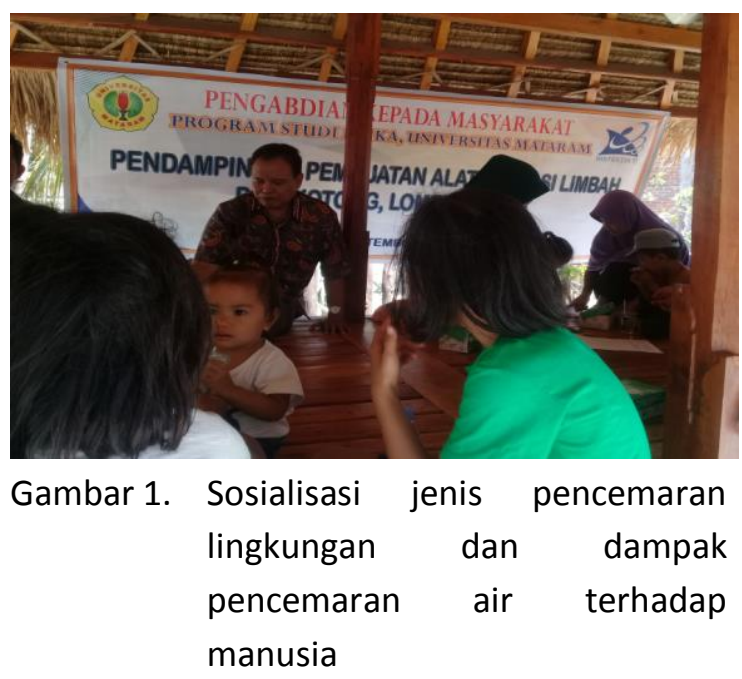

Setelah melalui tahapan kegiatan sosialisasi, warga diajak untuk membuat alat filtrasi sendiri. Adapun proses pembuatan ini terdiri dari pembuatan desain alat, persiapan alat dan bahan, membuat alat filtrasi, dan mengaplikasikan alat filtasi air. Pada proses awal dibuat desain alat filtrasi. Alat filtasi dibuat menggunakan peralatan dan bahan sederhana seperti paralon, batu apung, kerikil, pasir, arang kayu, ijok, dan spon seperti gambar dibawah ini

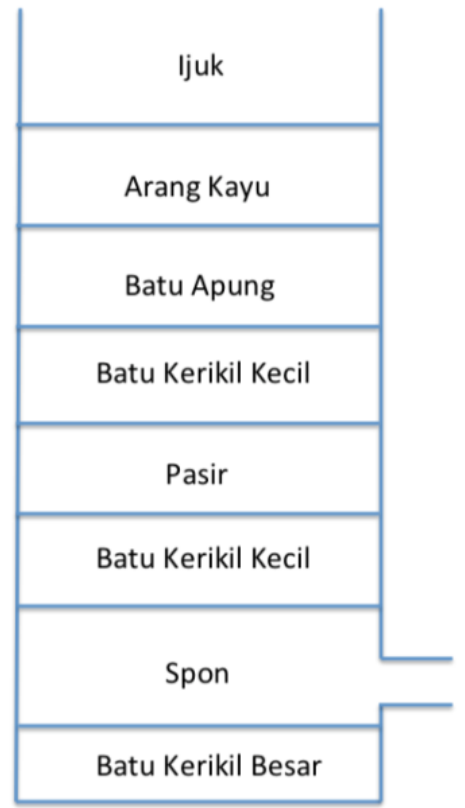

Gambar 2. Desain Alat Filtrasi berbasis kayu bnamunakau dan batu apung

Setiap material alam yang terdapat dalam alat filtrasi tersebut memiliki fungsi masing-masing yang saling melengkapi. Material ijuk merupakan bahan yang dimanfaatkan untuk menyaring kotoran pada air dalam ukuran partikel besar (terlihat oleh mata). Arang kayu dari kayu bakau ini sangat penting peranannya yaitu mampu sebagai absorben warna dan penyaring partikel ukuran lebih kecil. Setelah mampu mengubah warna air dan menyerap partikel lebih kecil, batu apung mengambil peranan sebagai penyerap logam berat. Seperti yang diketahui bahwa batu apung merupakan material bahan baku untuk membuat zeolit alat. Dimana zeolit alam ini sangat baik dimanfaatkan sebagai penyerap logam-logam berat. Meskipun proses penjernihan air ini sudah melalui tiga bahan penyaring, namun hasil yang diperoleh masih perlu bantuan material alam lain untuk mendapatkan air yang layak dipakai. 
Biasanya, air yang dihasilkan dari penyaringan menggunakan ijuk, arang kayu, dan batu apung masih menghasilkan warna hitam akibat dari warna alami arang. Sehingga perlu adanya penyerap lain untuk memperoleh air yang jernih. Penyerap yang sudah lumrah digunakan yaitu kerikil, pasir, dan spon. Penataan letak material kerikil, pasir dan spon seperti gambar 2 untuk menyaring parikel sangat kecil sehingga warna air yang dihasilkan jernih. Sedangkan peletakan batu kerikil besar pada bagian paling bawah memiliki peranan yang cukup penting juga yaitu sebagai penjernih tingkat akhir. Batu kerikil ini memiliki pori yang cukup besar sehingga mampu menyerap partikel kecil pada air. Dengan menggunakan prinsip-prinsip tersebut pada masing-masing bahan, kegiatan pengabdian dilanjutkan dengan proses pembuatan alat filtrasi.

Pada proses pembuatannya, desain gambar 2 digunakan untuk membuat alat filtrasi. Proses per proses dilakukan oleh warga dengan sangat antusias. Peralatan seperti paralon dipotong sesuai ukuran yang dibutuhkan. Adapun bahan-bahannya diletakkan berdasarkan desain yang sudah ada. Kemudian alat filtrasi diuji coba dengan menggunakan air sumur warga yang tercemar. Proses uji coba dilakukan bersama warga sekitar air sumur yang digunakan yaitu air yang keruh dan berbau. Dari hasil uji coba tersebut terlihat bahwa terjadi perubahan warna air dan bau yang menghilang. Secara fisis, metode ini mampu meningkatkan $\mathrm{PH}$, menurunkan $\mathrm{DHL}$, dan meningkatkan TDS air. Hal ini merujuk pada perubahan kualitas air.

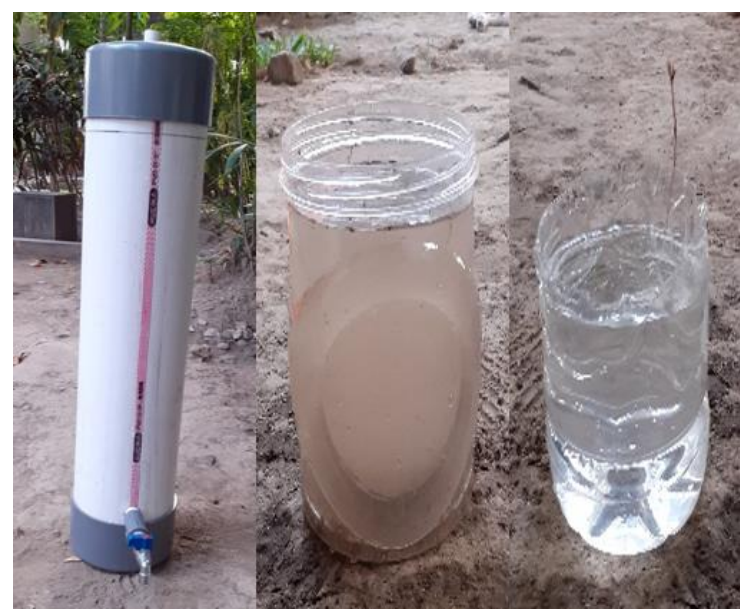

(a)

(c)
Gambar 3. (a) Alat filtrasi air silinder diameter 5 inci dengan tinggi 50 $\mathrm{cm}$ (b) Kondisi air sebelum filtrasi dan (c) Kondisi air setelah proses filtasi dengan rendemen $2 / 3$ volume awal

Setiap tahapan pembuatan alat filtrasi diikuti dengan antusias oleh warga. Tahapan akhir yang dilakukan yaitu tahap evaluasi. Tahap evaluasi dilakukan dengan metode Tanya jawab secara personal kepada warga. Dari hasil survey, banyak dari mereka yang tidak menduga bahwa bahan-bahan yang sering dijumpai dapat mereka manfaatkan sebagai penjernih air. Adapun hasil utama dari kegiatan ini yaitu masyarakat sudah mampu membuat dan mengaplikasikan alat penjernih air berbasis kayu bakau dan batu apung. Sehingga kegiatan ini dapat dijadikan model untuk memperoleh air layak pakai di daerah yang memiliki air tercemar. 


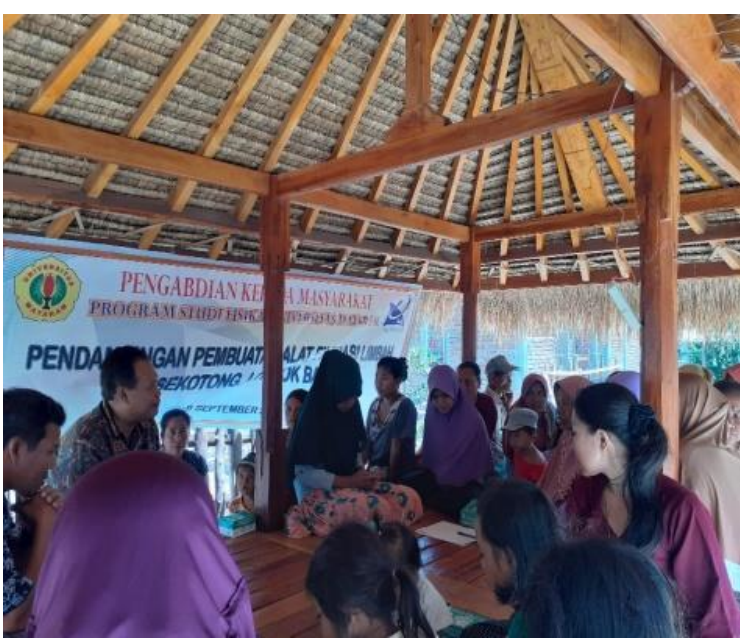

Gambar 4. Evaluasi kegiatan pengabdian

\section{KESIMPULAN DAN SARAN}

Pemanfaatan alat penjernih air berbasis kayu bakau dan batu apung di desa Pelangan, Sekotong Barat telah berhasil dilakukan. Kegiatan yang terdiri dari tiga tahapan yaitu sosialisasi, workshop, dan evaluasi kegiatan memperoleh respon positif dari warga sekitar. Respon tersebut ditunjukkan dengan antusiasme warga yang responsive dan mampu mengikuti kegiatan dengan baik. Bahkan warga mampu membuat alat sendiri untuk dimanfaatkan sebagai penjernih air demi memenuhi kebutuhan air untuk keperkuan rumah tangga. Air yang dihasilkan dari alat penjernih yang dibuat oleh warga mampu mengubah kualitas air baik dari warna maupun bau nya. Adapun saran yang perlu dilakukan yaitu melakukan upgrade ukuran alat penjernih air. Sehingga pembuatan alat ini menjadi salah satu solusi yang dapat diterapkan masyarakat desa pelangan untuk memperoleh air bersih.

\section{UCAPAN TERIMA KASIH}

Ucapan terima kasih kepada Universitas Mataram yang telah memberi dana pengabdian melalui dana DIPA BLU (PNBP) dengan no kontrak 2239/UN/LPPM/2019. Adapun ucapan terimakasih untuk tim pengabdian prodi fisika fakultas MIPA Universitas Mataram dan warga desa Pelangan yang memberikan fasilitas untuk terlaksananya pengabdian ini.

\section{DAFTAR PUSTAKA}

Alaa, S., Sumarlan, I., Rahayu, S., \& Kurniawidi, D. W. (2019). Sosialisasi Penjernih Air Komposit Karbon Aktif (KOMAK) Untuk Memperoleh Air Layak Pakai Kepada Masyarakat Pagutan Barat. Jurnal Warta Desa, 1.

Bahareh, Asadollahi Esfahani., Banafsheh, Asadollahi Esfahani., Mina, Shams Koupaei., \& S.Z. Ghasemi .(2014). Industrial waste water treatment by membrane systems," Indian Journal of Fundamental and Applied Life Sciences vol. 4 No, pp. 1168-1177.

Caroline, Jeny., Putra, K. Hadi., \& Tavares, M.E.D. Costa. (2017). Pengolahan Air Laut Menjadi Air Tawar dengan Menggunakan Karbon Aktif dari Akar Mangrove. Seminar Nasional sains dan Teknologi Terapan, h.12.

Ersoy, Bahri., Sarisik, ali., Dikmen, Sadef., \& Sarisik, Gencay. (2010) . Characterization of Acidic Pumice and Determination of Its Electrokinetic Properties in Water. Jurnal Powder Technology.

Fuadi, A. Ramdja., Kurniawan, Arif., \& Syeh, Ahmad. (2008). Pembuatan Karbon Aktif dari Coalite Batubara dan Aplikasinya dalam Pengolahan Limbah Cair Industri Kain Jumputan. Journal Teknik Kimia, h.1-2.

Kurniawidi, D. W., Handayani, C., Alaa, S., \& Rahayu, S. (2016). Activated Carbon 
Composites from Rice Husk as an Adsorbent Textile Waste. International Conference on Scinces and Technology, Mataram.

Kurniawidi, D.W., Alaa, S., Sukrisna, B., Syamsuddin, S., \& Rahayu,S. (2020). Implementasi Teknologi Filtrasi Air Dengan Komposit Dari Karbon Aktif dan Calsium Oxide Untuk Meningkatkan Kualitas Air. Jurnal Masyarakat Mandiri. Vol. 4 No.5.

Mourhly, Asmaa., Mariam, Khachani., Adnane, El Hamidi., Halim, Mohammed., \& Arsalen, Said. (2015). Synthesis and Characterization of Low-Cost Mesoporous Silica From Local Pumice
Rock. Jurnal Nanomaterial and Nanotechnology.

Sancayaningsih, Peni, R., \& Soetarto. (2010). Studi Kandungan Merkuri Pada Pertambangan Emas Tradisiona Di Kecamatan Sekotong, Lombok Barat. Repository UGM.

Sariwati E. (2010). Analisis beban pencemaran Sungai Cihideung sebagai bahan baku pengolahan air di Kampus IPB Dramaga [skripsi]. Bogor (ID) : Institut Pertanian Bogor

Trianasari., Manurung, Posman., \& Karokaro, Pulung. (2017). Analisis dan Karakterisasi kandungan Silika $\left(\mathrm{SiO}_{2}\right)$ sebagai Hasil Ekstraksi Batu Apung. Jurnal Teori dan Aplikasi Fisika. Vol.5 no.2 